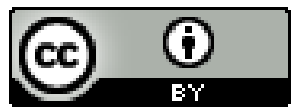

\title{
"NEGÓCIO AFRICANO": OCUPAÇÕES, ARRANJOS DE TRABALHO E PATRIMÔNIO DE MULHERES E HOMENS LIBERTOS DA COSTA NO RECIFE, SÉC. XIX ${ }^{1}$
}

Resumo: O presente artigo propõe-se a discutir alguns aspectos acerca das experiências de mulheres e homens africanos, suas estratégias para "viverem sobre si" e assegurarem seus espaços de sobrevivência no centro urbano na cidade do Recife em meados do século XIX. Apresento as ocupações e o patrimônio de pessoas libertas para analisar os mecanismos de afastamento dos estigmas impostos pela escravidão. Segui os rastros de um grupo formado por 33 africanos da Costa d'África em uma gama de fontes variadas (testamentos, inventários postmortem, livros de notas de tabeliães, jornais, registros paroquiais), para cotejar as condições materiais, e, sobretudo, os arranjos de trabalho que esses indivíduos organizaram ao longo de suas existências que lhes garantiram certa autonomia financeira, proporcionando rompimento com os laços senhoriais.

Palavras-chave: Africanos libertos. Ocupações. Arranjos de trabalho. Patrimônio. Recife oitocentista.

\section{"AFRICAN BUSINESS": OCCUPATIONS, WORK ARRANGEMENTS AND ASSETS OF WOMEN AND MEN FREED FROM THE COAST IN RECIFE IN THE 19 ${ }^{\text {TH }}$ CENTURY}

\begin{abstract}
This article aims to discuss some aspects about the experiences of African women and men, their strategies to "live on themselves" and ensure their survival

\footnotetext{
${ }^{1}$ Este texto é uma sítese de discussões mais amplas do $4^{\circ}$ capítulo de minha tese de doutorado Costa (2013). Parte dessas análises foram também apresentadas no X Encontro Estadual da ANPUH-PE, 2014. Agradeço as Professoras Dra. Solange Rocha da UFPB e Dra. Mariana Andrade pela leitura e sugestões a presente versão.

${ }^{2}$ Doutora em História Social/UFBA; Professora do IF Sertão PE, campus Serra Talhada; integrante do Grupo de Pesquisa O Mundo Atlântico da UFPE e do Dadá - Grupo de Pesquisas em Relações de Gênero, Sexualidade e Saúde da UFRPE/UAST; associada à ABPN; autora de É do dendê! História e memórias urbanas da nação Xambá no Recife, 1950-1992 (Annablume, 2009) e Coorganizadora de Religiões negras no Brasil da escravidão e da pós-emancipação (Selo Negro, 2016). Seus principais interesses de pesquisa concentram-se nos temas da escravidão, população africana em Pernambuco oitocentista, religiões da África e afro-brasileiras nos séculos XIX e XX, história das mulheres negras e relações de gênero. E-mail: valeriaodecosta@gmail.com
}

Revista da ABPN • v. 12, n. Ed. Especial - Caderno Temático: "Africanos, escravizados, libertos biografias, imagens e experiências atlânticas” • agosto de 2020, 


\section{Óman}

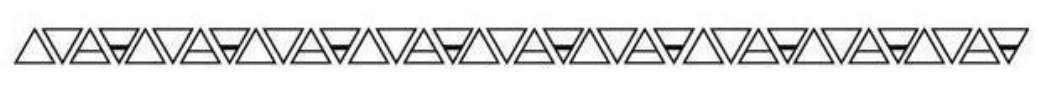

spaces in the urban center in the city of Recife in the middle of the 19th century. I present the occupations and assets of freed people to analyze the mechanisms for removing the stigmas imposed by slavery. I followed the tracks of a group of 33 Africans from the Africa's coast from a variety of sources (wills, post-mortem inventories, notary books, newspapers, parish records), to compare material conditions, and, above all, , the work arrangements that these individuals organized throughout their existences that guaranteed them a certain financial autonomy, providing a break with the lordships.

Keywords: Freed africans. Occupations. Work arrangements. Patrimony. Recife $19^{\text {th }}$ Century.

\section{"NEGOCIO AFRICANO": OCUPACIONES, ACUERDOS LABORALES Y BIENES DE MUJERES U HOMBRES LIBERADOS DE LA COSTA EN RECIFE EN EL SIGLO XIX}

Resumen: Este artículo tiene como objetivo discutir algunos aspectos sobre las experiencias de mujeres y hombres africanos, sus estrategias para "vivir de sí mismos" y garantizar sus espacios de supervivencia en el centro urbano de la ciudad de Recife a mediados del siglo XIX. Presento las ocupaciones y los bienes de las personas liberadas para analizar los mecanismos para eliminar los estigmas impuestos por la esclavitud. Seguí las huellas de un grupo de 33 africanos de la Costa d'África con una amplia variedad de fuentes (testamentos, inventarios post mortem, libros de anotaciones notariales, periódicos, registros parroquiales), para comparar las condiciones materiales $\mathrm{y}$, sobre todo, los acuerdos laborales que estos individuos organizaron a lo largo de sus existencias que les garantizaron una cierta autonomía financiera, proporcionando una ruptura con los señoríos.

Palabra clave: Africanos liberados. Ocupaciones. Acuerdos laborales. Patrimonio. Recife en el siglo XIX.

\section{"NÉGOCE AFRICAINE": OCCUPATION, CONDITIONS DE TRAVAIL DES FEMMES ET HOMMES LIBÉRÉS ET PATRIMOINE DES AFFRANCHIS DE COSTA À RECIFE, SIÈCLE. XIX}

Résumé: Cet article propose de discuter de certains aspects des expériences des femmes et des hommes africains, de leurs stratégies pour "vivre su eux-mêmes" et assurer leurs espaces de survie dans le centre urbain de la ville de Recife au milieu du XIXe siècle. Je presente les métiers et les atouts des personnes libérées pour analyser les mécanismes de suppression des stigmatese imposés par l'esclavage. J'ai suivi les traces d'um groupe de 33 africains de la Côte d'Afrique à partir de sources diverses (testaments, inventaires post-mortem, livres de notaire, journaux, registres paroissiaux), pour comparer les conditions matérielles, et surtout, les modalités de travail que ces individus organisaient tout au longe de leurs existences qui leur garantissaient une certaine autonomie financière, offrant une rupture avec les seigneuries.

Revista da ABPN • v. 12, n. Ed. Especial - Caderno Temático: "Africanos, escravizados, libertos biografias, imagens e experiências atlânticas" • agosto de 2020, 
Mots-clés: Africains libérés. Professions. Organisation du travail. Patrimoine. Recife du $19 \mathrm{e}$ siècle.

\section{INTRODUÇÃO}

A historiografia da escravidão trouxe consideráveis ponderações acerca das ocupações especializadas que poderiam - em algum aspecto - contribuir para a mobilidade social de mulheres e homens cativos, libertos e livres, atribuindo também certo prestígio aos sujeitos dentro de sua comunidade. Os indíviduos escravizados com qualificação mantinham relações mais próximas com os seus senhores, fator que ajudava na barganha de suas manumissões. Além do mais, livres e forros que desempenhavam serviço qualificado teriam maiores chances de inserção no mercado de trabalho. O ganho, por conseguinte, abriu um leque de possibilidades para as pessoas melhorarem suas condições de vida. Os "mundos do trabalho ao ganho" nas cidades apresentavam uma diversidade de funções que podiam ser executadas. Essa dinâmica obrigou um grande contingente de libertos a se especializar em algum ofício. No caso particular de mulheres e homens africanos, foram poucos os casos de sujeitos escravizados que desempenharam ofício especializado como sapateiros, alfaiates, costureiros(as), em sua maioria, libertos (OLIVEIRA, WISSENBACH, 1998; 1988, REIS, 2003: 373-379; FARIAS, et.al., 2006; REIS, 2019). Os centros urbanos, por outro lado, surgiam como espaços de melhor expectativa de vida, possibilitando oportunidades de serviços menos degradantes e mais autonomia. Mas, a realidade citadina não se distanciava tanto do meio rural. A antiga condição de escravização era sempre reabilitada nas relações de trabalho. Por não terem uma profissão, os indivíduos libertos saltavam de uma para outra atividade, orientados pela pessoalidade. Quanto às atividades que se lhes ofereciam - ou lhes restavam - eram sempre residuais, disputadas por escravizados, livres, brancos e negros pobres. Isto é, dos setores mais marginais aos mais emergentes da sociedade. Afora isto, as perspectivas para aqueles que continuavam nos engenhos e fazendas eram ínfimas. De cativos a agregados, enredados nas redes do paternalismo e sem ocupação qualificada, restavam-lhes trocar sua força de trabalho por moradia, alimentação e proteção.

Sob esta perspectiva, o presente artigo tem como pretensão fazer algumas

Revista da ABPN • v. 12, n. Ed. Especial - Caderno Temático: "Africanos,

escravizados, libertos biografias, imagens e experiências atlânticas" • agosto de 2020 , p. 288-319 
poderações sobre o cotidiano de trabalho e de negócios organizados por mulheres e homens africanos libertos cujas experiências estiveram atreladas às áreas urbanas do Recife, em meados do século XIX. Como estratégia, apresento narrativas de pessoas que deixaram rastros de suas vivências em testamentos, inventários post-mortem, registros paroquiais e cartoriais. Estas fontes não só ampliaram as lentes de observação das condições materiais dos sujeitos sociais, mas, sobretudo, dos serviços que os indivíduos desempenhavam ao longo de suas existências. Elenquei algumas questões como fios condutores da análise; quais as ocupações que podiam, de fato, as pessoas continuarem exercendo ou não depois de alforriadas? Quais mecanismos elaboraram para afastarem-se dos estigmas impostos pelo cativeiro, garantindo relativa emancipação financeira que lhes proporcionassem qualquer tipo de rompimento com os laços senhoriais?

Importa ressaltar que a utilização de inventários post-mortem e testamentos não é algo novo na produção historiográfica. Pesquisadores(as) interessados(as) na agência da população liberta e sua manutenção cotidiana valeram-se largamente dessa documentação. Kátia Mattoso (1979) e Maria Inês Cortes de Oliveira (1988) preconizaram os estudos dessas fontes para analisar a vida material e as redes de sociabilidades e negócios que mulheres e homens africanos e crioulos estiveram imersos na Bahia oitocentista. Dados relevantes neste campo também foram empreendidos por Sharyse Amaral (2007) e Gabriel Aladrén (2008). Amaral perscrutou como ex-escravizados em Cotinguiba (Sergipe), entre os anos de 1860 a 1888, geriam suas finanças, trabalho e as conexões entre africanos de uma mesma comunidade através de seus negócios. Ao seu turno, Aladrén serviu-se das informações sobre os bens arrolados em um corpus de 26 inventários de pessoas libertas para cotejar as ocupações e as transações nas quais os indivíduos estavam inseridos em Porto Alegre da primeira metade do século XIX. Ambos os historiadores fizeram inferências semelhantes quanto à situação econômica dos(as) forros(as), abandonando a ideia de uma total precariedade socioeconômica da liberdade. Ana Paula Schantz (2009) também avaliou o cabedal de mulheres e homens libertos em Porto Alegre e Viamão do final do século XVIII e início do século XIX, considerando que, naquelas regiões, mesmo não vivendo como indigentes, eles não se tornaram tão

Revista da ABPN • v. 12, n. Ed. Especial - Caderno Temático: "Africanos, escravizados, libertos biografias, imagens e experiências atlânticas" • agosto de 2020 , p. 288-319 
prósperos como os pesquisados por Amaral e Aladrén. ${ }^{3}$

Essa é uma discussão que tem como foco as estratégias do "viver sobre si" que mulheres e homens africanos libertos declararam em seus testamentos e/ou seus patrimônios arrolados em inventários, como conteúdo pertinente para pensar nas sobrevivências, arranjos de trabalho, parcerias, camaradagem nas áreas circunstanciais ou não de serviços, potencializadoras de chances para os sujeitos adquirirem relativa independência na sociedade escravista. Ou seja, os mundos do trabalho urbano ou rural nos quais as pessoas estavam emersas surgem como dado significativo para a reflexão acerca das rupturas e/ou continuidades dos forros com os laços senhoriais. Ademais, é importante destacar que os inventários abrangem apenas a parcela mais privilegiada da sociedade, cujo número era deveras pequeno. A grande maioria da população morreu sem legar patrimônio ou seus bens eram tão irrisórios sendo desnecessário o arrolamento judicial desses indivíduos (GOMES, SOARES In: SOARES, 2007, p. 191-224).

No conjunto documental que utilizei para construção das argumentações, destaco os testamentos e os inventários post mortem que foram registrados e/ou abertos entre os anos 1846 a 1890. Neste ínterim de tempo, a cidade do Recife passava por uma série de transformações decorrentes das efervescências da modernização que chegavam à província através do crescimento do comércio, implantação de fábricas, construção de novas pontes e prédios públicos, como a Casa de Detenção - no bairro popular de São José em 1851 - e a ponte Duarte Coelho construída em 1860. A capital pernambucana, como as demais cidades do território imperial brasileiro, esforçava-se para concretizar seus projetos "civilizatórios", empenhando-se no combate aos costumes africanos. Por sua vez, as camadas populares ressignificavam seus modos de viver, trabalhar, morar, constituir família, divertir-se, sepultar seus mortos, etc. A população liberta (africana e crioula) crescia a partir da intensificação de suas próprias lutas pela liberdade aliadas à política governamental de abolição gradual da escravatura e aos movimentos abolicionistas. Os dados do censo de 1872, por exemplo, apontaram que no Recife habitava uma

\footnotetext{
${ }^{3}$ Alguns(mas) historiadores(as) vêm trazendo para o debate experiências individuais e coletivas de libertos(as) que adquiriram relativa afluência, ampliando as discussões em torno da situação econômica desse grupo social. Consultar: FARIA, 2000; GUEDES, 2008; COSTA, 2013.
}

Revista da ABPN • v. 12, n. Ed. Especial - Caderno Temático: "Africanos, escravizados, libertos biografias, imagens e experiências atlânticas” • agosto de 2020, p. 288-319 
média de 1.859 pessoas advindas de África (946 livres e 913 escravizadas). Deste número, 80\% (747 libertos(as) 446 cativos(as)) era de mulheres e homens forros e residentes nos quatro bairros centrais (Recife, Santo Antônio, São José e Boa Vista) (COSTA, 2013, p. 36-37).

\section{MUNDOS DO TRABALHO URBANO}

Ao longo do século XIX, a organização do trabalho nas cidades não só permitia a confluência de atividades produtivas, funções de abastecimento e serviços, ocupações paralelas e meios suspeitos de sobrevivência, como também introduzia diversos tipos de trabalhadores e de trabalhadoras. À exceção dos criados, que até meados do Oitocentos eram sempre cativos, não havia divisões rígidas entre mulheres e homens trabalhadores escravizados, libertos ou livres. Os meios compulsório e remunerado do labor coexistiram, assim como outras formas combinavam elementos de ambos. Escravizados ao ganho, tutelados como diaristas e assalariados, africanos livres, brancos e mestiços, pessoas livres pobres faziam parte de uma mesma paisagem da lide urbana (WISSENBACH, 1998: 74-75). ${ }^{4}$

Por outro lado, ao mesmo tempo em que a cidade agregava diversos tipos de serviços, categorais de trabalhadores e trabalhadoras individualizavam os sujeitos. Em contrapartida, as qualificações promoviam identidades coletivas. No caso particular da população negra, podemos citar alguns exemplos. No Recife, muitos homens escravizados e libertos pretos e pardos eram canoeiros. Na capital pernambucana chegaram a ser até sinônimos os termos "negro" e "canoeiro". No Rio de Janeiro, as mulheres vendeiras que monopolizavam o comércio de quitanda eram chamadas de "pretas minas". Os escravizados e libertos ganhadores nas ruas de Salvador exerciam múltiplos afazeres, organizavam-se por etnias nos cantos, turmas, forjando também identificações (CARVALHO, 1997; REIS, 2000, p. 199; SILVA, 2016).

Para Maria Inês Cortes de Oliveira (1988), as chances de ocupação na área urbana dependiam de certas variáveis relacionadas à utilização da mão de obra escravizada, estando em jogo, contudo, o interesse do senhor. Este era primordial e

\footnotetext{
${ }^{4}$ Entre os estudos sobre trabalho urbano na sociedade escravista recifense consultar: MAC CORD, 2012.
}

Revista da ABPN • v. 12, n. Ed. Especial - Caderno Temático: "Africanos, 
desenhava o traçado das relações de laboração no escravismo. Como detentor da força de trabalho escravo, ficava a cargo do proprietário decidir "quem", "como", "onde", "sob quais condições" e "qual ocupação seria exercida". Obviamente, todas essas decisões eram pensadas de acordo com o nível de riqueza e prestígio do senhor, seu contingente de cativos e o comportamento do mercado. Esses fatores incidiam diretamente na necessidade de treinar ou não o escravizado em algum ofício; assim como se o(a) cativo(a) iria lavorar e sob que espécie de vínculo empregatício. Segundo, os atributos individuais da pessoa escravizada, dos quais dependeria a sua qualificação. O sexo, a idade, a origem - africano ou crioulo (mulato, pardo, cabra, semibranco) ${ }^{5}$-, a força física, o comportamento, entre outros, eram alguns dos fatores que poderiam influenciar de forma positiva ou negativa. As oportunidades de mobilidade estavam muitas vezes correlacionadas a estas questões. Nesse contexto, aqueles que conseguiam ser encaminhados para qualificação teriam, consequentemente, maiores expectações de conquistar a liberdade. Ao se tornarem libertos, dependendo do ofício adquirido, inseriam-se ou não no "mundo" do trabalho livre. Terceiro, eram as condições do mercado de trabalho que ditavam os ensejos para a atividade especializada (OLIVEIRA, 1988, p. 13).

As relações laborais e as ocupações, por seu turno, exerciam certa influência na mobilidade social de mulheres e homens escravizados, isto é, nas reais possibilidades de eles adquirirem suas manumissões. Segundo Henrique Espada (2009), os contratos de serviços, enquanto vigoraram, representaram pertinente busca de emancipação pelos libertos, uma vez que se tratava de um instrumento público e o contratante teria que cumprir as regras nele estabelecidas. Os contratos de serviços, por sua vez, garantiam não só a possibilidade de alforria aos escravizados, mas, sobretudo, brechas para os libertos se colocarem no mercado de trabalho. Comumente, havia duas modalidades de contrato. A primeira, ocorria quando a pessoa escravizada resgatava adiantado o valor de sua alforria, obrigando-se a um determinado tempo de serviço para a quitação da dívida. Os indivíduos neste pacto ficavam em maior contato com o senhor, sob condições de subserviência, obediência, tendo sua mobilidade bastante restrita. Na

\footnotetext{
${ }^{5}$ A categoria de cor de pele "semibranco" é corrente na documentação eclesiástica de Pernambuco desde o início do século XIX. Ver entre outros trabalhos que abordam o tema é: (LIMA, 2003; BARROS, 2017).
}

Revista da ABPN • v. 12, n. Ed. Especial - Caderno Temático: "Africanos, escravizados, libertos biografias, imagens e experiências atlânticas” • agosto de 2020, p. 288-319 
segunda modalidade, estavam os arranjos de trabalho com certo grau de flexibiliade, a exemplo dos cativos ao ganho, cuja responsabilidade era entregar aos seus senhores, periodicamente, o abono monetário fixado. Porém, este tipo de contrato era mais comum entre indivíduos forros. No Recife, os serviços de alfândega e do porto eram destinados mais aos africanos do que aos crioulos - carregadores de fardos, trapicheiros, pilotos de barca, marinheiros. Por conseguinte, as negras africanas vendeiras de alimentos e frutas também se destacavam no comércio ambulante em freguesias como Santo Antônio e São Frei Pedro Gonsalves do Recife (KOSTER, 2002, p. 66-67; OLIVEIRA, 1988, p. 18-20; CARVALHO, 1998).

\section{OCUPAÇÕES E NEGÓCIOS DE MULHERES E HOMENS AFLUENTES DA COSTA D'ÁFRICA}

Mas, quais eram, afinal, as atividades econômicas que proporcionaram melhores condições de vida às pessoas de origem africana que prepararam testamentos ou tiveram seus bens inventariados?

$\mathrm{Na}$ amostra de 31 testamentos e treze inventários post-mortem registrados e abertos entre os anos de 1846 a $1890,{ }^{6}$ apenas dois homens com trabalho manual qualificado e duas mulheres domésticas informaram do que viviam economicamente. ${ }^{7}$ A preta africana Luduvina Maria da Conceição foi uma das ex-amas de leite que relatou a ocupação do tempo de cativa, todavia não informou sobre suas atividades econômicas depois de forra. Declarou ser seu ganho insuficiente para a sobrevivência. Mesmo assim, conseguiu ter sua morada em solo próprio. Um imóvel que passou o longo da sua vida para quitar, endividando-se com seus ex-senhores, que também custeavam seus medicamentos e alimentação. Ou seja, a mantendo nas redes de

\footnotetext{
${ }^{6}$ Destes 31 testamentos, 2 foram elaborados por casais, o que perfaz o número de 33 pessoas testadoras. Entretanto, acompanhei um número bem maior de africanos.

7 Oliveira (1988, p. 15) organizou as ocupações dos escravizados e libertos em manuais (sem qualificação, semiqualificadas e qualificadas) e não manuais. Estas últimas diziam respeito aqueles indivíduos que gerenciavam seus próprios negócios: tabernas, tendas de barbeiros, roças, quintadas, etc. Dentre as atividades manuais qualificadas, estavam açogueiros/talhadores de carne, marinheiros, artistas, enfermeiros, sapateiros, etc. Enquanto nas semiqualicadas estavam mucamas, amas de leite e secas, lavadeiras, pajens. Já as não qualificadas eram estivadores, carregadores, serventes. Cf. Costa (2013, p. 162-169).
}

Revista da ABPN • v. 12, n. Ed. Especial - Caderno Temático: "Africanos, escravizados, libertos biografias, imagens e experiências atlânticas” • agosto de 2020, p. 288-319 
dependência senhorial. Por sua vez, o liberto Sirio Manoel Ribeiro Taques, natural da Costa da África, declarou "viver do negócio de talhar carne verde". Era um dos mais desafortunados entre os testadores, porém se considerava robusto e apto a ampliar seu patrimônio antes de falecer. Declarou possuir poucos móveis, casa, uma "escrava" e um sítio (COSTA, 2013, p. 157).

O marinheiro Duarte José Martins da Costa, mina savalu, embora tenha obtido algum lucro na profissão, quando não pôde mais exercê-la ficou em precária situação financeira. Os bens resumiram-se em uma cativa que comprou à prestação, ainda por quintar a última parcela, parcos móveis usados do lar. Aguardava receber um dinheiro pelo trabalho que fez em sua derradeira viagem marítima, totalizando uma média de 969 mil réis. Também contraíu uma dívida de 100 mil réis - para o seu tratamento de saúde - e até o dia 04 de abril de 1854, data que elaborou seu testamento, não havia quitado. A faina de marinheiro era uma das mais duras para um homem, fosse branco ou negro, africano ou brasileiro. Vivia sob extrema subordinação, às vezes submetido a castigos e maus tratos, com baixa remuneração, suscetível de se tornar indigente. Os negros, porém, foram as maiores vítimas, senão de violência física, dos preconceitos. Não há nenhuma informação a respeito de africanos ou crioulos que ascenderam na hierarquia da marinha no século XIX. Porém, muitos deles, ao se engajar como marinheiros, conseguiam trilhar os caminhos de suas liberdades. Alguns, na esperança de se alforriar após longos períodos a bordo; outros, a exemplo de Duarte, almejando ser reconhecidos por seu trabalho e bem remunerados, para dar continuidade aos seus projetos de autonomia.

Oliveira (1988, p. 34-35) constatou ser comum entre mulheres e homens libertos não indicarem suas ocupações porque viviam dos serviços prestados pelos seus cativos no ganho ou alugados, representando sua principal fonte de renda. O gentio de nação calabar José Antônio Lopes, após a sua manumissão, passou a viver quase exclusivamente dos lucros do trabalho de seus cativos e das transações de compra e venda de escravizados. ${ }^{8}$ A literatura salietou que a posse de cativos não representou só um meio de vida, a exemplo da poupança, mas também companhia

8 Cf. Memorial de Justiça de Pernambuco (MJPE), mapoteca 12, gaveta G, Lv. 8 (14/11/1850 a 31/3/1853), Testamento de José Antônio Lopes, 1849, fl. 2v-4.

Revista da ABPN • v. 12, n. Ed. Especial - Caderno Temático: "Africanos, escravizados, libertos biografias, imagens e experiências atlânticas” • agosto de 2020, p. 288-319 
para os(as) proprietários(as). Voltarei a este debate mais adiante, tecendo algumas considerações a partir da documentação utilizada neste artigo.

Não obstante, embora poucos tenham deixado rastros de seus serviços, aproximo-me das atividades econômicas de alguns sujeitos sociais, cotejo outros meios de sobrevivência além da posse cativa, utilizando como recurso a análise das redes pessoais reveladas nos seus testamentos e os bens arrolados em seus inventários post-mortem. Constato que poucos continuaram exercendo as mesmas funções do tempo de cativeiro e não conseguiram ampliar suas perspectivas de vida. Estes representaram $10 \%$ no pequeno universo de 33 pessoas que faziam parte da comunidade africana afluente do Recife. Este foi o caso de Antônio Domingos Ferreira, africano de nação angico, membro da Irmandade de São Christovão dos Canoeiros, morador do Beco do Tocolombó, no bairro do Recife. Área onde se concentrava o grosso da população masculina de libertos e cativos. Lugar do comércio de exportação e importação, atividades portuárias, como a carga e descarga de balsas e navios, eram predominantes. Na primeira metade do século XIX, era espaço de confluência dos negros canoeiros, como o angico Antônio Domingos. Esta profissão foi bastante lucrativa, mas foi decliniando na medida em que a escravidão se diluía nas última décadas do século XIX (CARVALHO, 1997, p.93). Muitos foram obrigados a mudar de ramo por não terem mais vigor físico, enquanto outros já não conseguiam obter lucros tão vantajosos de outrora. O angigo Antônio é um exemplo disto; seus bens eram tão irrisórios que nem inventário foi aberto. ${ }^{9}$

Alguns, como o caso do cassange João Joaquim José de Sant'Anna, aliaram a profissão a uma outra ocupação. Ele era porteiro no Arsenal de Marinha e costumava investir na usura. Entre seus bens além da casa e um terreiro que deveria ser usado para arcar com as despesas de inventário, havia mobílias em bom estado de conservação, peças de ornamentação e utilidade doméstica de ouro, prata e cobre. Produtos que podiam lhe reder bom dinheiro nos momentos de apertos financeiros. Comumente, nas residências dos forros africanos, predominava mobiliário velho, usado e em mau estado de conservação, até entre aqueles possuidores de cabedal.

\footnotetext{
${ }^{9}$ Cf. MJPE, mapoteca 12, gav. G, Lv. 8 (14/11/1850 a 31/3/1853), Testamento de Antonio Domingos Ferreira, 1846, fl. 102v-103v.
}

Revista da ABPN • v. 12, n. Ed. Especial - Caderno Temático: "Africanos, escravizados, libertos biografias, imagens e experiências atlânticas” • agosto de 2020, p. 288-319 
Mas, João Joaquim desviou-se deste padrão (COSTA, 2013, p. 110). Faria (1998) e Silva (1997) teceram inferências sobre a cultura material como indicativo de distinção social. Isto é, mais um elemento pertinente para verificar as condições econômicas e meios de sobrevivência da população liberta.

Ressalto, contudo, que poucos foram os negociantes negros que chegaram a ter uma vida socioeconômica elevada para o padrão dos egressos do cativeiro. O Diário de Pernambuco noticiou o embarque para a Costa d'África de um "grande número de africanos livres, ${ }^{10}$ que há muitos anos viviam entre nós negociando [...] e hoje, possuindo não pequena fortuna, cada um deles retira-se para a sua Pátria". Pode-se deduzir pelo anúnico que foi possível certo acúmulo de capital por africanos dedicados ao comércio de ovos, peixes, cocos e outras frutas, ou seja, de comida e iguarias pelas ruas de todo o litoral da Província (MELLO, 1996, p. 73). ${ }^{11}$ Presumo ainda a existência de dois perfis de sujeitos que diziam viver de seus negócios. $\mathrm{O}$ primeiro, classifico como negociante de médio porte, pois sustentava-se das rendas de seus imóveis (a partir de dez prédios), havendo, pois, vários cativos (dez ou mais) no ganho. O segundo, pequeno negociante, vivia do comércio a retalhos ou possuía um modesto estabelecimento como a taberna ou ainda extraía lucros de seus prédios (no máximo dois) de aluguel. Russel-Wood (2005) tratando do período colonial, realçou que afora a agricultura, o comércio seria o meio mais rápido para as mulheres e os homens libertos e livres negros terem uma vida estável ao ascenderem socialmente. No ramo do comércio - mesmo competindo diretamente com os brancos - as possibilidades de acúmulo de pecúlio seriam maiores, sobretudo na cidade. No entanto, o máximo que poderiam ser eram proprietários de mercadorias ou tabernas (RUSSEL-WOOD, 2005, p. 89-90), isto é, pequenos negociantes como defini anteriormente. Especulo que as observações de Russel-Wood podem ser extendidas aos meados do século XIX, visto que entre os africanos libertos que deixaram patrimônio relativo, envolveram-se com tais ramos de negócios, como apontaram Reis (2008) e Faria (2000).

Entre as pessoas que classifico como pequenas negociantes, há aquelas que se

${ }^{10}$ Leia-se como "africanos livres", nesta matéria, as pessoas libertas que conquistaram suas manumissões no Brasil.

${ }^{11}$ Cf. Grifo meu.

Revista da ABPN • v. 12, n. Ed. Especial - Caderno Temático: "Africanos, escravizados, libertos biografias, imagens e experiências atlânticas” • agosto de 2020, 
tornaram donas de tabernas, como a angola Margarida Maria da Conceição e o casal mina Francisco Afonso Martins Caneiro e Joaquina da Conceição Araújo. Margarida era moradora da Rua Porto das Canoas, na Freguesia de São Frei Pedro Gonçalves do Recife. Segundo seu testemunho, havia financiado a própria alforria, embora não tenha declarado o valor que pagou ao ex-senhor Jozé Lopes de Oliveira, a quem ainda deixou um legado de 10 mil réis. Ela era casada com o português Jozé Pereira com quem dividia a propriedade de uma das seis tabernas que existiam na rua da Senzala Nova. ${ }^{12}$ Embora o estabelecimento fosse registrado no nome de seu esposo e tratandose de uma sociedade patriarcal, na qual as mulheres negras estavam em diferentes nuances de subordianção e opressão, sendo quase inconcebivel para uma africana ter igual direitos e mando no que diz respeito ao patrimônio da familia, suponho que Margarida não se limitou às atribuições domésticas e auxílio do marido na lida da taberna, lavando louça, preparando comida ou até atendendo à clientela. $\mathrm{O}$ matrimônio do casal foi em comunhão de bens, o codicilo foi elaborado conjuntamente, declararam ser herdeiro e testamenteiro um do outro. A propriedade daquele comércio, enfim, era compartilhada. O patrimônio de ambos era formado pela taberna, uma casa e 100 mil réis. Mesmo informando uma dívida de 40 mil réis, disseram não ter "nenhum constrangimento que por fallecimento de nós ambos fiquem os remanescentes das duas meações daquillo que possa existir..." ${ }^{13}$ Ou seja, para Margarida e seu cônjuge, o comércio proporcionava-lhes ter uma vida modesta, sem muitas privações.

A taberna do casal mina Francisco Afonso Martins Carneiro e Joaquina da Conceição Araújo ficava no bairro de São José. Dentre os quatro bairros centrais, este era o mais pobre e o terceiro mais populoso. ${ }^{14}$ Nesse local concentrava-se a maior parte da população negra em busca de trabalho, pois era onde surgiam as maiores

\footnotetext{
${ }^{12}$ Arquivo Público Estadual Jordão Emereciano (APEJE), Folhinha de Algibeira, 1849, fl. 204; 1850, fl. 199; 1851, vol. 1, fl. 235; 1852, fl. 281.

${ }^{13}$ MJPE, map. 12, gav. G, Lv. Lv. 8 (14/11/1850 a 31/03/1853), Registro de testamento de Margarida Maria da Conceição, 1852, fl.88v-90; fl. 89.

${ }^{14}$ Formavam o principal centro urbano da cidade do Recife os seguintes bairros: Recife (região portuária) que agregava as freguesias de Fora de Portas e São Frei Pedro Gonsalves; Santo Antônio (antiga Ilha de Antônio Vaz) que se desmembrou em 1842 da área ao sul, onde surgiu São José; e Boa Vista, parte continental. Este era o mais populoso dentre os bairros e de maior concentração de habitantes de origem africana; o segundo era o Recife. Cf. Costa (2013, p. 73-81).
}

Revista da ABPN • v. 12, n. Ed. Especial - Caderno Temático: "Africanos, escravizados, libertos biografias, imagens e experiências atlânticas” • agosto de 2020, p. 288-319 
oportunidades, embora circunstanciais, de serviços. Outro dado interessante está no fato de que as pretas africanas, mesmo após conquistar a alforria, preferiam fixar residência em São José, tão embora, fosse no bairro da Boa Vista, o lugar de moradia mais comum da população africana. Em 1851, o nome de Francisco Afonso figurava entre os dezoito proprietários de bodega na rua Imperial. ${ }^{15}$ Especulo que um dos mecanismos utilizados pelo casal para driblar a concorrência foi manter uma boa relação com a vizinhança, pois todas as testemunhas do testamento de Francisco Afonso residiam naquele bairro. ${ }^{16}$

Ademais, mesmo o número de tabernas sendo tão grande quanto o de casas que existiam no local, a concorrência era acentuada para Francisco Afonso e Joaquina da Conceição. Além do mais, a clientela deveria se resumir a negros(as) ao ganho, libertos(as) e livres pobres que consumiam mais fiado do que à vista no estabelecimento. Por essa razão, supunho que a complementação da renda deles era a comercialização das frutas existentes na propriedade em que moravam. O sítio ficava na mesma rua da taberna - outrora chamado de "Pirão gordo" - e era formado por duas casas de tijolos e cal, cacimba e árvores de frutas. O antigo nome da propriedade sugere que ali funcionasse uma espécie de casa de angu onde cativos, libertos e livres sem posses realizavam refeições e aproveitavam para se sociabilizarem. Quando Francisco Afonso e Joaquina da Conceição compraram a propriedade em 1851 já havia uma das casas, provavelmente onde funcionava a venda de alimentos, frutas ou verduras destinada à população local. ${ }^{17}$ Não encontrei, todavia, nenhum indício do casal mantendo esse tipo de atividade econômica, pois fizeram do sítio local de residência e passaram a viver dos lucros da taberna. Deste comércio, o casal adquiriu a propriedade, construiu a segunda casa avaliada em 1:500\$000 (hum conto e quinhentos mil) réis, ou seja, $500 \$ 000$ réis mais cara que a antiga moradia existente no terreno. Francisco Afonso também contava com uma poupança que dava para

\footnotetext{
${ }^{15}$ APEJE, Follhinha de Algibeira, 1853, vol. 2, fl. 243-244.

${ }^{16}$ Francisco José Martins da Costa, Valdevino Ribeiro da Silva, Joze Bernardino Alves, Joaquim José de Olinda Tavares, José Leão de Mello, todos moradores no São José. Cf. MJPE, map. 13, gav. F, , Lv. 1866-1868, fls. 32-34 e 39-41v (repetido), Registro de Testamento de Joaquina da Conceição Araújo, 1867, fl. 33.

${ }^{17}$ Instituto Arqueológico, Histórico, Geográfico Pernambucano (IAHGP), Inventário de Joaquina da Conceição Araujo, 1867, cx. 172, fl. 23v. Sobre as casas de angu, consultar Soares (1988, p. 31-44).
}

Revista da ABPN • v. 12, n. Ed. Especial - Caderno Temático: "Africanos, escravizados, libertos biografias, imagens e experiências atlânticas” • agosto de 2020, p. 288-319 
emprestar algum dinheiro aos amigos, como aquele cassange João Joaquim José de Sant'Anna que era porteiro no Arsenal da Marinha a quem Francisco Afonso emprestou $100 \$ 000$ réis. $^{18}$

Portanto, os pretos minas Francisco Afonso e Joaquina da Conceição podem ser considerados como pequenos comerciantes com certa estabilidade de vida financeira. Imóveis avaliados em 2:500\$000 réis, mais algum dinheiro que poupavam com os lucros da taberna e - acredito que - também da venda das frutas da chácara. Entretanto, a partir dos anos 1860, o casal sofreu abalos econômicos. Contraíram dívidas com seus vizinhos da rua, chegando até a hipotecar a propriedade onde moravam.

$\mathrm{Na}$ segunda metade do século XIX, o comércio a retalhos estava monopolizado pelos portugueses, como outrora acontecera na época da Revolução Praieira (1848), quando os lusos eram "senhores absolutos do comércio" que ocasionou a revolta dos brasileiros. ${ }^{19}$ Nos anos 1850 , havia poucos brasileiros entre os lojistas de fazendas, donos de casas de ferragens e miudezas, armazéns de recolher carne-seca e até dos de açúcar - a aristocracia do comércio -, com uma exceção aqui e acolá, os proprietários eram portugueses. Até tabernas e padarias situadas nas principais ruas da cidade estavam sob monopólio dos lusos, ao contrário das de brasileiros, localizadas em becos tapados, travessas, camboas e instaladas em casebres distantes do centro urbano (FREYRE, 2004, p. 386).

Se os brasileiros estavam prejudicados pela concorrência com os portugueses, o que diríamos dos libertos africanos? Os minas Francisco Afonso e Joaquina da Conceição enfrentavam uma dupla concorrência: de um lado, os grandes possuídores de estabelecimentos de grosso trato portugueses; de outro lado, os médios e pequenos comerciantes brasileiros. A solução encontrada pelo casal foi tomar empréstimos de dinheiro a juros, como já destacado anteriormente. Um dos empréstimos fora concedido por Manoel Martins Pires, vizinho de rua de Francisco Afonso e Joaquina. Pires assegurou $500 \$ 000$ réis ao casal para serem pagos dentro de dezoito meses, com

\footnotetext{
${ }^{18}$ IAHGP, Testamento e Inventário de João Joaquim José de Sant'Anna, 1862, cx. 179.

19 Consultar (CÂMARA, 2012) acerca do comércio a "retalhos" em Pernambuco, no século XIX, dominado pelos portugueses.
}

Revista da ABPN • v. 12, n. Ed. Especial - Caderno Temático: "Africanos, escravizados, libertos biografias, imagens e experiências atlânticas” • agosto de 2020 , p. 288-319 
juros de $2 \%{ }^{20}$ Como garantia da quitação da dívida, o sítio foi hipotecado por Pires no dia 9 de agosto de 1866. Antes do prazo, no dia 29 de julho de 1867, Francisco já havia conseguido quitar não só os juros mensais, mas também pagar o valor principal de sua dívida, evitando assim perder sua propriedade. Mas não retornou à estabilidade financeira de outrora, como casas, sítios, pontos comerciais.

Tudo indica que dentre os pequenos negociantes, aqueles que viviam de rendas de seus poucos imóveis e cativos tiveram menos prejuízos que os taberneiros. O africano de nação costa Domingos José Machado, habitante da Freguesia de São Frei Pedro Gonsalves do Recife, foi um dos poucos comerciantes que conseguiram viver até os últimos dias de sua existência sem comprometer seus bens ou recorrer a vultosos empréstimos de dinheiro para as suas necessidades cotidianas. ${ }^{21}$ À primeira vista, o africano Domingos não passava de um mero liberto com apenas um teto para morar, sustentando-se do aluguel do sobradinho (casa de dois andares) que possuía na rua do Apolo, por trás da rua da Guia, onde estava situada sua residência. Os fragmentos de sua trajetória revelam, porém, que, ao longo de sua vida, além do aluguel da casa, ele viveu das rendas de seus cativos e foi um negociante bem relacionado para além da comunidade negra. Entre as décadas de 1840 e 1860, ele possuiu pelo menos quatro escravizados: uma cativa adulta e três "crias". ${ }^{22}$ É relevante dizer que as "crias" de Domingos eram frutos de sua cativa Benedicta, mãe de todos os demais escravizados. Talvez, a preferência dele por mulheres estivesse no lucro obtido dos rebentos delas, vendendo ou ampliando seus braços para o trabalho. Penso, ainda, que Benedicta não fora a única escravizada de Domingos e que, portanto, ele tivera outros ao longo de sua existência. Quando elaborou seu testamento em 1890, Domingos informou apenas um mero patrimônio de 5:942\$000 réis. Seu legado estava constituído por móveis e imóveis no valor de 3:942\$000 réis, mais dois contos de réis em dinheiro guardado na Caixa Econômica. Dinheiro

\footnotetext{
${ }^{20}$ IAHGP, Inventário de Joaquina da Conceição Araujo, 1867, cx. 172, fl. 25.

${ }^{21}$ IAHGP, Testamento e Inventário de Domingos José Machado, 1890, cx. 335.

${ }^{22}$ Arquivos da Cúria Metropolitana do Recife e Olinda (ACMRO), Registro de batismo da parda Josefa, filha natural de Benedicta, escravas de Domingos José Machado, LB 27 (1855-1862), 13/06/1858, fl. 76v; Registro de batismo do crioulo Luiz, filho natural de Benedicta, escravos de Domingos José Machado, LB 27 (1855-1862), 09/12/1860, fl. 159; Registro de batismo de Feliciano, crioulo, filho natural de Benedicta, escravos de Domingos José Machado com Maria Francisca da Conceição, LB 26 (1851-1855), 03/09/1854, fl. 79v.
}

Revista da ABPN • v. 12, n. Ed. Especial - Caderno Temático: "Africanos, escravizados, libertos biografias, imagens e experiências atlânticas” • agosto de 2020, p. 288-319 
utilizado pela viúva Maria Francisca Machado para arcar com as despesas de inventário e ficar amparada com um teto para morar (COSTA, 2011, p. 187-188).

O avançar do século, contudo, acirrou ainda mais a concorrência no mercado com imigrantes europeus - portugueses no comércio a retalhos e ingleses nos negócios de grosso trato - e as chances dos libertos foram se restringindo. Além do mais, os códigos e projetos de leis - após 1835 - elaboravam estratégias, cada vez mais, para limitar o fluxo do comércio protagonizado por mulheres e homens africanos libertos que transitavam entre o Brasil e a África, negociando produtos religiosos que atraíam muita gente, em especial africanos e crioulos. Apesar disso, na década de 1880, os códigos racializadores foram se sedimentando e as limitações na área do trabalho assalariado e no comércio aumentaram substancialmente para a gente negra. Por conseguinte, houve a queda nos negócios que refletiu no empobrecimento de mulheres e homens negros brasileiros e, sobretudo, africanos.

\section{O PATRIMÔNIO E O STATUS}

Embora seja lugar comum atribuir pobreza às mulheres e aos homens libertos ou no máximo - pequenas posses como as trajetórias aqui narradas, houve aqueles que conquistaram uma vida socioeconômica mais confortável se compararmos ao padrão comum da população sem posses e negra que viveu em sociedades escravistas. A historiografia mais recente vem reavaliando a ideia de precariedade da liberdade dos ex-cativos de origem africana, mas ainda são parcos os estudos. Sheila Faria (2000) teceu considerações sobre as possibilidades dos libertos angariarem notável cabedal, sobremaneira as mulheres da Costa da Mina. Para ela, este grupo social atingiu um patamar econômico de destaque que chegou a ser o segundo índice de riqueza em São João Del Rei setecentista (FARIA, 2000, p. 65-90). Embora discorde em parte da afirmativa generalizante de Faria, há de se considerar que as africanas minas criaram estratégias de acúmulo de pecúlio, que lhes deram certo prestígio socioeconômico. Viajantes europeus do século XIX já registravam a existência de libertos buscando distanciamento das marcas do cativeiro através de esforços para acumular dinheiro. Maria Graham (1990) observou, no Recife da década de 1820,

Revista da ABPN • v. 12, n. Ed. Especial - Caderno Temático: "Africanos, escravizados, libertos biografias, imagens e experiências atlânticas" • agosto de 2020 , p. 288-319 
como alguns deles chegaram a ficar "ricos". Assim, como Russel-Wood corroborou, ela considerava o comércio e a agricultura como os principais meios de estabilidade da população negra. Segundo a inglesa:

Um negro livre, quando sua loja ou sua roça corresponde ao seu esforço, vestindo-o e a sua mulher com um belo fato preto, um colar e pulseiras para a senhora, e fivelas nos joelhos e sapatos para adornar as meias de seda, raramente se esforça muito mais, e contenta-se com sua alimentação diária (GRAHAM, 1990, p. 57).

Graham, assim como Russel-Wood, estão tratando do período colonial, mas cogito que ela se precipitou ao afirmar que os libertos contentavam-se apenas com suas necessidades diárias após o acúmulo de algum cabedal. Para meados do século XIX o cenário é de forros que continuavam - mesmo depois de aumentarem suas perspectivas financeiras - nas atividades exercidas quando cativos ou nas novas ocupações agenciadas na liberdade. Além do mais, nas trajetórias das mulheres e homens africanos que perscrutei foi possível verificar como construir patrimônio significava também distanciar-se do cativeiro, através de liderança política na comunidade e na busca de inserção em outros espaços sociais.

Investigando o patrimônio dos indivíduos, por meio de seus inventários postmortem, foi possivel cotejar os sentidos e os significados de mobilidade socioeconômica e até que ponto os africanos libertos ampliaram seus horizontes de expectativas de vida. A utilização desta fonte se torna indispensável, pois só se abria inventário do espólio que deixasse bens significativos. No caso de mulheres e homens africanos, ainda, por não terem pais ou outros parentes no Brasil, sendo muitas vezes casados, mas não tendo filhos, o arrolamento de bens era desnecessário quando se tinha testamento. Das 33 pessoas que elaboraram testamento, apenas treze indivíduos e dois casais abriram inventário.

Os bens se resumiam em casas, sítios, joias, móveis usados, algum dinheiro e cativos. Sublinho que as joias e os escravizados representavam um investimento semelhante à poupança, prontos para serem utilizados em momentos de crises econômicas. Não obstante, o montante do espólio muitas vezes não dava para cobrir as despesas com a partilha, sendo referido processo apenas pró-forma, cito Maria Thereza dos Passos, cujo patrimônio - avaliado em 259\$000 réis - resumia-se a um

Revista da ABPN • v. 12, n. Ed. Especial - Caderno Temático: "Africanos, escravizados, libertos biografias, imagens e experiências atlânticas” • agosto de 2020, p. 288-319 
cordão de ouro pesando três oitavas e meia. No caso da preta de nação Costa Gertrudes Joana Florinda, cujo patrimônio foi avaliado em $952 \$ 100$ réis, os bens eram muito poucos e seus herdeiros não tinham condições de arcar com os custos do inventário. Utilizaram o reduzido patrimônio - a casa e parcas joias - para bancar as despesas com a partilha. Acabaram ficando sem nada, pois os custos foram mais elevados que o valor do patrimônio. ${ }^{23}$ Essas africanas não foram os únicos casos de precariedade financeira; outros, mesmo que tivessem bens consideráveis, terminaram ao final de suas vidas em difícil situação econômica, sobretudo os pequenos negociantes.

Entre os bens arrolados nos inventários ou declarados em testamentos, no período de 1846 a 1890, foram extraídas as seguintes informações: 20 pessoas proprietárias de imóveis urbanos; 2 na área rural; 7 indivíduos declararam-se possuidores de joias; 17 donas de cativos; e apenas 2 com dinheiro no banco.

Pernambuco não promulgou leis provinciais que cerceassem mulheres e homens nascidos na África à posse de bens de raiz como na Bahia, mas o reduzido número de donos de sítios localizados fora da cidade sugere o quanto era difícil o acúmulo de pecúlio para as pessoas da África. Mais do que isto, para aquelas que conseguiam distinção econômica, seriam necessárias extensas redes sociais para poder adquirir tal bem. Quase sempre, as propriedades rurais eram compradas a comendadores, grandes negociantes, militares de alta patente, indivíduos brancos. Quanto às poucas pessoas com dinheiro corrente, no momento do inventário, pode ser que os sujeitos estivessem sempre investindo seu cabedal, seja em propriedades ou emprestando dinheiro a juros a outrem.

$\mathrm{Na}$ comunidade, apenas 13,3\% de pessoas conquistaram um patrimônio que garantiu não só desfrutarem de prestígio socioeconômico, mas assegurar para seus descendentes - até a terceira geração - padrão de vida elevado. Denominei de negociantes de médio porte pessoas como o casal de pretos minas Alexandre Rodrigues d'Almeida e sua esposa Thereza de Jesus e Souza; e Maria Antônia de Souza, africana de nação calabar e seu esposo José Francisco da Costa, de nação

\footnotetext{
${ }^{23}$ IAHGP, Inventário de Maria Thereza, 1888, cx. 328, fl. 2; Inventário de Gertrudes Florinda, 1877, cx.
} 250, fl. 14-20v e 24.

Revista da ABPN • v. 12, n. Ed. Especial - Caderno Temático: "Africanos, escravizados, libertos biografias, imagens e experiências atlânticas” • agosto de 2020, p. 288-319 
Costa. $^{24}$

O casal mina Alexandre Rodrigues e Thereza de Jesus era o mais afortunado. Eles eram naturais da Costa da Mina, libertos e moradores da rua da Conquista, no bairro da Boa Vista. Como já aludi, a localidade era onde confluía a população africana forra e com algum quinhão. Casaram-se no dia 10 de fevereiro de 1855, por carta de ametade na Matriz do Santíssimo Sacramento de Santo Antônio do Recife, e permaneceram juntos até 1873, quando Thereza faleceu. Enquanto casal, não conceberam filhos ou filhas, mas deixaram várias pessoas como afilhadas e herdeiras de seu patrimônio. Em 1873, quando foi elaborado o testamento de Thereza, a fazenda do casal foi avaliada em 30:487\$000 (trinta contos quatrocentos e oitenta e sete mil) réis, distribuídas em prédios de aluguéis, escravizados, móveis e objetos que lhes conferiam status, pontos comerciais. Ao ficar viúvo, Alexandre ampliou seus bens chegando em 1880 à cifra de 36:705\$840 réis. Foi neste período que ele começou a se dedicar ao comérico de taberna. Comparando-se aos homens brancos de negócios, em particular, europeus estabelecidos em Pernambuco, podemos dizer que Alexandre e Thereza se tornaram pessoas bem prósperas e afluentes. Entre os comerciantes ricos e abastados fixados na província, analisados por Bruno Câmara (2012), o afamado comerciante inglês Henry Gibson - radicado em Pernambuco desde 1834 - teve seu espólio avalidado em 52:811\$770 (CÂMARA, 2012, p. 341) em 1873, por ocasião da assinatura do contrato nupcial entre uma de suas filhas e o futuro noivo, para a proteção da herança deixada pelo pai. Gibson era caixeiro que se dedicou ao comércio de fazendas de "grosso trato". ${ }^{25}$

Alexandre tinha atividades econômicas diversificadas: alugava imóveis; empregava cativas "ao ganho", como a preta de nação Maria, de 44 anos de idade, que era quitandeira; e possuía uma taberna na rua do Riachuelo, no mesmo bairro de sua residência. Sugiro ainda que mercadejassem tecidos, roupas ou pequenos objetos, pois foram arrolados entre seus bens seis baús, sendo quatro de flandres e dois de carro. Porém, a principal fonte de renda deles foi aquela proveniente de aluguéis dos

${ }^{24}$ IAHGP, Inventários de Alexandre Rodrigues d'Almeida, 1880, cx. 269; Thereza de Jesus e Souza, 1873, cx. 229; Maria Antônia de Souza e José Francisco da Costa, 1872, cx. 214.

${ }^{25}$ Segundo Câmara (2012) os comerciantes de Pernambuco, inclusive portugueses e alguns ingleses que faziam grandes fortunas, investiam em compras de imóveis, sobrados para locação de moradias e portos comerciais.

Revista da ABPN • v. 12, n. Ed. Especial - Caderno Temático: "Africanos, escravizados, libertos biografias, imagens e experiências atlânticas" • agosto de 2020 , p. 288-319 
prédios que possuíam, espalhados pelo centro da cidade do Recife. Só na rua em que moravam (a rua da Conquista), havia três casas e os dois portões - espécie de conjunto residencial - que comportavam quatro meias-águas e seis pequenos quartos com apenas uma porta e sem janelas e mais cinco outras residências na vizinhança. Nos bairros de Santo Antônio e São José, comprou sete prédios, duas casas na rua de Santa Rita; e no bairro do Recife, possuía três casas na Rua de São Jorge. ${ }^{26}$

Quando ficou viúvo, seus negócios continuaram crescendo. Aumentou não só o número de imóveis para 25, como também ampliou o valor de seu patrimônio como apontei. Além de passar a ser taberneiro, como aludi, realizou diversas reformas nos imóveis que de meias-águas passaram a ser espécie de pensionato com vários quartos de locação, ampliando o número de inquilinos.

Embora o quinhão do casal Maria Antônia, de nação Cabalar e José Francisco, de nação Costa não se equiparasse aos de Alexandre e Thereza, pois seus bens foram avaliados em 16:240\$760 réis, eles também atingiram um patamar socioeconômico de prestígio e, assim, como seus patrícios, viviam dos aluguéis de seus imóveis e das rendas de seus cativos. Residiam na rua Marquês do Herval, no bairro de Santo Antônio, lugar de intenso comércio da cidade. No ano de 1852, o periódico Folhinhas de Algibeira registrou a existência, no bairro, de cinquenta lojas de produtos para o varejo e o atacado, como boticas, armazéns de fazendas em grosso, lojas de calçados, lojas de chapéus, miudezas, lojas de armadores, empórios de carne-seca, de farinha de mandioca, casas de gêneros, ourives, relojoarias, livrarias, casas de vendas de cativos, entre outros ramos. ${ }^{27}$ Neste mesmo bairro, Maria Antonia e José Francisco possuíam seis casas (quatro avaliadas em 3:000\$000 réis): quatro na mesma rua que habitavam; uma na Travessa do Prata; e uma no Beco do Dique, ambas em São José; e um sítio nos arrabaldes de Água Fria. Possuíam seis escravizados, sendo duas cozinheiras, dois para o serviço doméstico e uma que estava fugida, cuja ocupação não fora identificada e um velho africano de 80 anos que não prestava mais serviço. Entre os bens arrolados, constaram também três banquinhas amarelas velhas utilizadas pelas

${ }^{26}$ Cf. Inventários de Thereza de Jesus e Souza, 1873; e Alexandre Rodrigues d'Almeida, 1880, cx. 269,fl. 122v; COSTA, In: XAVIER, FARIAS, GOMES: 2012, p. 98-111.

${ }^{27}$ APEJE, Folhinhas de Algibeira, 1852, fl. 261-331.

Revista da ABPN • v. 12, n. Ed. Especial - Caderno Temático: "Africanos, escravizados, libertos biografias, imagens e experiências atlânticas” • agosto de 2020, p. 288-319 
cativas para mercadejar os quitutes preparados na residência de seus senhores. ${ }^{28}$

Ao classificar estas pessoas como médios negociantes, considero não só o patrimônio, mas, sobretudo, se eram devedoras e se os débitos não comprometiam seu legado. Maria Antônia e José Francisco, ao contrário do casal mina Alexandre e Thereza, morreram sem deixar dívidas para serem quitadas. Além do mais, eles estavam dentro de uma teia social com comerciantes de grosso trato, como Manoel Alves Guerra, um dos negociantes mais bem aquinhoados do Recife, que comercializava fazendas de tecidos no atacado. Seu estabelecimento, inicialmente, fixou-se na rua da Aurora (bairro da Boa Vista), mas se transferiu em 1851 para a rua da Cruz (Boa Vista). Neste mesmo ano, deixou o comando do armazém sob a responsabilidade do filho Manoel Alves Guerra Júnior. Além do ramo têxtil, foi proprietário de diversos cativos. Todavia, Maria Antônia e José Francisco não foram no passado escravizados por Alves Guerra. A relação entre o casal e o comerciante estabeleceu-se depois de terem conquistado a alforria. É possível que a ligação entre o casal e Guerra fosse pautada nos negócios mesmo, sobretudo com Maria Antônia. Talvez ela fosse uma cliente de Guerra. Uma das agências de comércio das mulheres da Costa da Mina, em Salvador e no Rio de Janeiro, foi o estabelecimento de relações com negociantes de grosso trato que as tinham como suas freguesas. Fato que estendo ao Recife por meio da experiência da mina Maria Antônia. ${ }^{29}$

Vale ressaltar que a rede tecida com negociantes de grosso trato, profissionais liberais, entre outros grupos sociais, não foi uma peculiaridade de Maria Antônia e José Francisco. Era característica dessa comunidade de africanos que cotegei, tecerem redes sociais, políticas e econômicas com pessoas que ostentavam prestígio na sociedade recifense. Afora comerciantes de grosso trato, mantiveram relações com caixeiros, grandes proprietários, funcionários públicos (oficiais de justiça, amanuenses de cartório e escrivães), militares e ocupantes de serviços especializados como alfaiates, carpinas, artistas, trabalhadores portuários (armador, tráfico do porto e piloto de barca), soldadores, pedreiros e ganhadores, isto é, pessoas pretas, brancas, pardas, africanas, brasileiras e portuguesas. O sucesso ou fracasso dos negócios

${ }^{28}$ IAHGP, Inventário de Maria Antônia de Souza, 15-17v.

${ }^{29}$ APEJE, Folhinha de Algibeira, 1848, fl. 198; 1849, fl. 179; 1851, fl. 209; 1852, fl. 252 e 263. Cf. (GOMES \& SOARES In: SOARES, 2007, p. 197).

Revista da ABPN • v. 12, n. Ed. Especial - Caderno Temático: "Africanos, escravizados, libertos biografias, imagens e experiências atlânticas” • agosto de 2020, p. 288-319 
dependia, de certo modo, de tais malhas construídas. Ou seja, um verdadeiro campo negro - expressão utilizada por Flávio Gomes - era agenciado pelos indivíduos para se distanciarem dos estigmas da escravidão.

Experiências bem-sucedidas como as dos minas Alexandre, Thereza, Maria Antônia e José Francisco - mais do que generalizações - sugerem que mesmo em uma sociedade hierarquizada (e racializada) com mecanismos de sucessão de papéis e status sociais amplamente predeterminados, havia - embora raros - espaços para empreendedores como os exemplos dessas pessoas de origem africana descritas nesta narrativa.

\section{POSSE CATIVA: UM DADO RELEVANTE NA COMPOSIÇÃO DO PATRIMÔNIO DOS LIBERTOS}

Outro aspecto que considero importante para a reflexão acerca da sobrevivência dos indivíduos é a propriedade escrava. Embora tenha sido ansiada também por mulheres e homens libertos, poucos foram aqueles que conseguiram ser donos de cativos. Este era o segundo investimento mais procurado pelas pessoas, fossem elas brancas ou negras. No grupo de 33 pessoas, 17 indivíduos foram alguma vez, ao longo da vida, proprietários de escravizados. Mas a maioria chegou a ter no máximo dois cativos, corroborando a historiografia, que afirma o quanto era alto o custo dessa propriedade (OLIVEIRA, 1988; FARIA, 2000; REIS, 2008). Tendo em vista que a posse cativa era um indicativo do nível de riqueza ou de pobreza, como destacou Oliveira (1988), abrindo possibilidades de aquisição de outros bens, não se pode considerar mulheres e homens africanos como pessoas que atingiram níveis elevados de distinção social como os indivíduos brancos. No grupo de africanos libertos que perquiri, os homens se destacaram como proprietários de cativos, ${ }^{30}$ embora a historiografia atribua às mulheres maior facilidade para adquirir cativos, seja pelo fato de, ao serem manumitidas, receberem de seus ex-senhores, "escravos" para iniciar a vida em liberdade; seja pelo trabalho, como meretrizes ou comerciantes, inclusive as quitandeiras. Isto é, as chances de acúmulo de pecúlio seriam mais amplas para as

3022 mulheres e 11 homens.

Revista da ABPN • v. 12, n. Ed. Especial - Caderno Temático: "Africanos, escravizados, libertos biografias, imagens e experiências atlânticas” • agosto de 2020, p. 288-319 
libertas do sexo feminino (OLIVEIRA, 1988, p. 43; FARIA, 2000, p. 160-161). Devido ao fato de minha amostragem ser pequena (um grupo de 17 indivíduos), não descarto que, no Recife, as africanas libertas também fossem, como em outras regiões brasileiras, as maiores proprietárias de cativos. Porém, são necessárias investigações mais sistemáticas para confirmar tal premissa.

$\mathrm{Na}$ minha amostra, as mulheres alforriaram mais do que os homens. Elas representaram 55,5\% dos(as) donos(as) de escravizados(as) que concederam alforria em testamento, inclusive sob prestação de serviços por tempo determinado ou após a sua morte. Tal vantagem feminina na concessão da manumissão significa que as mulheres utilizavam-se desse mecanismo, mais do que os homens, para extrair melhores serviços de seus cativos. Era também uma forma de valer-se de autoridade para "domar" os sujeitos escravizados, inclusive para as mulheres solteiras e viúvas, que precisavam controlar sozinhas seus "escravos" (OLIVEIRA, 1988, p. 46). Já foi dito que as solteiras e as viúvas se destacavam como donas de cativos, devido à ausência da rede de parentesco e à idade avançada.

A escravidão faz parte da história da humanidade e suas transformações, ao longo do tempo, não se restringiram ao Continente Africano. Portanto, numa sociedade escravista, um dos pressupostos para se afirmar como indivíduo livre e economicamente bem aquinhoado era ser "senhor de escravos". Patterson (2008), por sua vez, ao tratar da África, evidencia que para as pessoas forras, sempre consideradas sem honra, a propriedade cativa era uma maneira de exercer poder e possuir status. Na região do Sudão Central, em particular, a posse de escravizados representava distinção social. Os cativos raramente eram utilizados como meio de produção, seu uso como agente para o comércio externo, como nas Américas, comumente era acompanhado pela ascensão de uma classe mercantil ou guerreira. Em regiões muito pobres, constituía uma mercadoria para a viabilização de riqueza. Era também o único bem que os mais desfavorecidos poderiam oferecer aos mais ricos, daí sua aquisição para conquistar mobilidade social (PATERSSON, 2008, p. 220). No Brasil, mulheres e homens libertos de origem africana passaram a utilizar a mão de obra escravizada como indicativo de

Revista da ABPN • v. 12, n. Ed. Especial - Caderno Temático: "Africanos, escravizados, libertos biografias, imagens e experiências atlânticas” • agosto de 2020, p. 288-319 
distanciamento do cativeiro. Destaco, no entanto, que as pessoas nascidas livres se sobressaíram mais do que as forras como proprietárias de "escravos".

Há de se considerar algumas diferenças entre a posse cativa por mulheres e homens africanos na própria África e nas Américas. Nas sociedades africanas, devido ao fato de a propriedade da terra ser coletiva, a posse de pessoas para serem utilizadas como mão de obra era a base legal de enriquecimento. Embora a escravidão fosse amplamente difundida, seu desenvolvimento foi independente do comércio atlântico. Todavia, a intensificação deste, com os seus vultosos lucros, estimulou o comércio interno de escravizados e os seus desdobramentos, ocasionando uma escravização mais intensa (THORNTON, 2004, p. 124-125).

Outra questão a ser observada é que, além do cativo ser o caminho mais seguro para a geração de riqueza, ele era também utilizado pelos funcionários do Estado na África como um grupo dependente, tanto na geração de renda como na administração e no serviço militar, nas lutas entre reis e dirigentes ansiosos pela centralização de seus Estados, e outras elites preocupadas em estabelecer o poder real. Contudo, o escravizado como meio de viabilização de acúmulo de riqueza e transmissão de herança tornou-se, sem dúvida, a forma mais notável da utilização de sua mão de obra na África. Os julas são um exemplo, entre os diversos grupos islâmicos do Sudão Central e da Senegâmbia, que se destacaram como promotores desse tipo de escravização (THORNTON, 2004, p. 138-144).

No entanto, ao avaliar no Brasil a posse de cativos por libertos de origem africana, outras questões devem ser consideradas, como a etnicidade e o sexo. Oliveira apontou que comumente os africanos davam preferência aos escravizados de sua mesma origem de nascimento. Mulheres e homens minas, em particular, na hora da aquisição cativa privilegiavam os escravizados de sua mesma procedência. Ou seja, poderia ocorrer o fato de nagô ter cativo nagô, mina adquirir escravo mina savalú ou mina calabar e assim por diante. Várias questões levavam um(a) africano(a) liberto(a) a adquirir cativos entre os de sua própria "nação". Escolhas pessoais, fatores culturais como a língua, laços de solidariedade permeavam tais seleções (OLIVEIRA, 1996, p.

Revista da ABPN • v. 12, n. Ed. Especial - Caderno Temático: "Africanos, escravizados, libertos biografias, imagens e experiências atlânticas" • agosto de 2020 , p. 288-319 
188). Contudo, dos proprietários de cativos do grupo de 33 pessoas, apenas três indivíduos e dois casais possuíram escravizados de sua mesma procedência. Luzia Muniz, preta da Costa da Mina, de nação savalú, possuiu três cativos, sendo dois da Costa da Mina; o calabar José Antônio Lopes teve dois escravizados de sua mesma nação; Lauriana, que era da Costa d'África, foi "senhora" de uma preta de nação Costa; e o casal mina Alexandre Rodrigues e Thereza de Jesus possuíram quatro pretas de nação Costa. O cassange João Joaquim teve um cativo de nação congo, ou seja, do mesmo eixo no qual foi traficado.

Um dado que merece ser considerado na questão da posse cativa é a "seleção étnica". O controle sobre o comércio de importação, cada vez mais acirrado, sobretudo após a Lei de 1833, pode ter incidido na escolha do escravizado que se pretendia adquirir. Uma das escravizadas do casal mina savalu Luzia Muniz e Manoel Maxado (sic) era de nação Quissamã. Isto é, da região centro-ocidental. ${ }^{31}$

Os cativos nascidos na África representavam 33,3\% dos escravizados do grupo aqui considerado. Duas hipóteses podem ser elaboradas. A primeira é que o fato de terem sido utilizados os testamentos e inventários post-mortem como principais fontes para estudar a propriedade cativa só tornou possível tomar conhecimento dos cativos em posse do indivíduo nos últimos momentos de sua vida, encobrindo sua trajetória, na qual, talvez, tivesse sido possuidor de mais "escravos" africanos. A segunda é que, como a maioria das aquisições desses escravizados ocorreu nos anos de repressão ao tráfico atlântico, o valor do sujeito escravizado ficou bastante alto. $\mathrm{O}$ maior número de crioulos cativos deve-se ao fato de serem filhos das cativas dos africanos libertos.

Quanto ao sexo, as "escravas" femininas também se sobressaíam entre os sujeitos escravizados dos africanos. Conjecturo que elas eram preferidas não só em razão do menor custo no mercado e de outras vantagens já comentadas, mas, sobremaneira pela possibilidade do aumento da posse cativa através da reprodução. No dia 3 de julho de 1877, nascia a cativa Paula, filha de Maria, uma das escravizadas do mina Alexandre Rodrigues. ${ }^{32}$ Segundo Thornton (2004), na África, as mulheres

\footnotetext{
${ }^{31}$ Sobre a propriedade escrava por libertos e a "seleção étnica", consultar (REIS, 2003).

${ }^{32}$ Arquivos da Matriz do Santísssimo Sacramento da Boa Vista (AMSSBV), Assento de batismo de Paula, preta, filha natural de Maria, escrava de Alexandre Rodrigues d'Almeida, 14/04/1878, LB, 13, fl.35v.
}

Revista da ABPN • v. 12, n. Ed. Especial - Caderno Temático: "Africanos, escravizados, libertos biografias, imagens e experiências atlânticas" • agosto de 2020 , p. 288-319 
capturadas nas emboscadas eram vendidas no mercado interno aos homens, pois o comércio atlântico solicitava com mais frequência cativos do sexo masculino. Porém, algumas experiências da escravização de mulheres foram reproduzidas nas Américas. Por exemplo, o que ocorria nas ilhas Bijagós (Guiné-Bissau), onde o contingente de escravizadas foi tão significativo que elas passaram a fazer parte de todo o processo produtivo, replicou-se no Continente Americano (OLIVEIRA, 1996, p. 164).

Não é menos importante ressaltar que a posse de escravizados, além de conferir status e possibilidades de enriquecimento, ampliava e fortalecia os negócios entre os próprios africanos, através das redes sociais. Na comunidade, foi comum não só comprar cativos a parentes de nação, a exemplo dos savalú Luzia Muniz e Duarte José Martins da Costa, mas, principalmente, confiar o apadrinhamento dos escravizados a patrícios. O calabar João Antônio Lopes priorizou como padrinhos de seus cativos outros africanos. Uma de suas escravas, a crioula Galdina, foi batizada pelo africano do gentio da Costa José Nicolao, que vivia de seus negócios, tinha uma extensa relação de comércio e amizades com pardos e brancos, negociantes, ganhadores, além de funcionários públicos. Estiveram entre as testemunhas de seu testamento os pardos Marcolino Joaquim da Paixão, armador; Domingos Francisco da Costa, ganhador; Francisco Gomes de Santa Anna, alfaiate; e o escrevente de cartório, Thomaz Correia Peres. Os que viviam de sua propriedade e do comércio de grosso trato eram José Veríssimo dos Anjos e Francisco Xavier Carneiro, homens brancos. Todos, assim como os libertos africanos que conseguiram alguma distinção econômica, também possuíam cativos. José Nicolao, quando elaborou seu testamento, declarou ser dono apenas de duas escravizadas, a crioulinha Martinha e sua mãe. Martinha ficou coartada na metade de seu valor para ser libertada após a morte de José Nicolao. Percorrendo, no entanto, as páginas dos livros de batismo da Igreja do Corpo Santo e da Matriz de Santo Antônio do Recife, encontrei-o com proprietário do escravizado Ignacio. ${ }^{33}$

A posse de escravizados por mulheres e homens africanos libertos, a exemplo do africano da Costa José Nicolao e todos os demais apresentados ao longo deste texto, leva a reflexão mais uma vez sobre o senhorio de escravos e a precariedade da liberdade

${ }^{33}$ MJPE, mapoteca 12, gaveta G, Lv. 8 (14/11/1850 a 31/01/1853), Registro de Testamento de José Nicolao, fl. 109v-112v; ACMRO, LB 25 (1848-1851); Registro de batismo de Luzia, parda, padrinho Ignacio escravo de José Nicolao, 25/11/1850 fl. 92.

Revista da ABPN • v. 12, n. Ed. Especial - Caderno Temático: "Africanos, escravizados, libertos biografias, imagens e experiências atlânticas” • agosto de 2020, p. 288-319 
(CHALHOUB, 2010). Embora a propriedade de pelo menos um cativo já fosse por si só um indício de diferenciação social, isto não significava levar uma vida distante das dificuldades passadas pela população pobre e sem posses, inclusive cativa. Além de serem utilizados como auxiliares no trabalho, os escravizados de africanos eram negociados em momentos de privação financeira. Na metade do século XIX, tais privações passaram a ser quase uma constante. As transformações urbanas e o advento da modernidade (monopolização do comércio por estrangeiros, maiormente portugueses, a queda no valor de seus imóveis, entre outros) foram outros motivos para a desvalorização do patrimônio dos libertos. Daí sempre recorrerem à venda de seus cativos para arcar com os custos de sua manutenção cotidiana. Por isto, ao analisar testamentos e inventários post-mortem, esbarra-se na ausência desse bem ou com o seu comprometimento para arcar com despesas de partilha.

\section{CONSIDERAÇÕES FINAIS}

Quais ocupações, portanto, as mulheres e os homens africanos desempenharam depois da conquista da alforria que lhes garantiram certa autonomia e rompimento com os laços senhorais? Procurei no transcorrer desta narrativa apontar alguns mecanismos agenciados pelas pessoas, para se desvencilharem dos estigmas da escravidão pelas vias do trabalho livre e remunerado. Notadamente, os sujeitos que viveram ao ganho e desta atividade partiram para o ramo dos negócios (aluguéis de imóveis, tabernas, posse de cativos) adquiriram maiores chances de construção de certa independência. Os estudos da escravidão e da liberdade no mundo atlântico sugeriram que, embora tenham sido poucos, houve experiências de libertos de origem africana que chegaram a acumular dinheiro e distinguirem-se do ponto de vista social e econômico. Porém, no avançar do século XIX, os indivíduos foram passando por um processo de descensão social, em decorrência das transformações na sociedade que iam gradualmente abandonando o escravismo, ao passo que ressignificavam seus aparatos racializadores. Neste aspecto, alguns fatores acarretaram a precarização da vida dos africanos após angariarem - no decurso de suas existências - cabedal. Como exemplos cito: festas, gastos com procissões de santos de devoção, confrarias católicas, pedidos para ter

Revista da ABPN • v. 12, n. Ed. Especial - Caderno Temático: "Africanos, escravizados, libertos biografias, imagens e experiências atlânticas” • agosto de 2020, 
funeral luxuoso, compra de joias que depois eram legadas aos seus herdeiros. Havia dificuldades para a manutenção de seus negócios, pois levavam desvantagens em relação aos brasileiros, em particular, os brancos sempre preferidos na hora de tratativas comerciais e arranjos de trabalho na área urbana. O ramo de comércio foi, sem dúvidas, também o que mais favoreceu a ampliação das redes de sociabilidades dos indivíduos africanos para além do seu grupo. Porém, eles tinham que provar - dia após dia - sua condição de liberdade, no caso dos forros, e se esforçavam para permanecer no mercado de trabalho. Na pesquisa que resultou neste trabalho, $43,8 \%$ das pessoas brancas que estabeleceram algum tipo de ligação com libertos da Costa d'África eram negociantes de grande e médio porte.

Saliento, por outro lado, que esse debate sobre os meios de sobrevivências de mulheres e homens libertos deve estar articulado, também, às preocupações da história social do trabalho. A historiografia da segunda metade do século $\mathrm{XX}$ empenhou-se em discussões acerca da - hoje superada - ideia de "transiçao" da escravidão para o trabalho livre. ${ }^{34}$ Os estudiosos, como frisou Silva Lara (1998), pareciam tratar de "dois Brasis", tendo como divisor de águas o 13 de maio de 1888. ${ }^{35}$ Até então, a história do trabalho livre (assalariado) para não dizer do operariado, excluía, assim, as experiências dos trabalhadores e das trabalhadoras escravizados e libertos. Entre os intelectuais, destaco Florestan Fernades que, mesmo considerando que o ex-escravizado renegava serviços que o colocasse em situações - moral ou física - análogas aos tempos de cativeiro, não deu devida atenção à agency dos indivíduos. Buscando, sob esta perspectiva, contextualizar as razões pelas quais as pessoas abandonavam lavouras e serem - equivocadamente - classificadas como “vadias”, “irresponsáveis" e “indisciplinadas" (FERNANDES, 2008, p. 46, 88, 90). Não dando atenção às greves nos trapiches e portos de meados do século XIX, encampandas pelos negros das estivas de cidades como Rio de Janeiro e Salvador. Ou ainda, as disputas entre negros e brancos, africanos, brasileiros e europeus em espaços circunstanciais de serviços nas áreas urbanas, como ferrovias (REIS, 2019; SOUZA,

${ }^{34}$ Cf. Gomes (2005 [1995]) e Freire (1996), os quais figuram entre os pioneiros estudos que focalizaram as experiências dos escravizados e libertos dentro da abordagem da história social do trabalho no Brasil. 35 Cf. Lara (1998) trouxe relevantes críticas à ideia de uma "transição" da escravidão para o assalariamento que vigorou entre as décadas de 1950 a 1970, fazendo um balanço da literatura dos anos 1990 que se contrapôs a esta visão.

Revista da ABPN • v. 12, n. Ed. Especial - Caderno Temático: "Africanos, escravizados, libertos biografias, imagens e experiências atlânticas” • agosto de 2020, p. 288-319 
2011).

Enfim, como realçou Lara (1998, p. 38), durante algum tempo os historiadores e as historiadoras se deixaram levar pelo espírito de Rui Barbosa e aparagaram da história social do trabalho no Brasil a "nódoa" da escravidão, obliterando a presença de "escravos" e libertos entre as massas de trabalhadores e trabalhadoras. Notadamente, ainda são recentes os esforços empreendidos pelos intelectuais para devolverem o protagonismo dos sujeitos sociais negros.

\section{REFERÊNCIAS BIBLIOGRÁFICAS}

ACMRO, Livros de Batismos (LB) 25 (1848-1851); 26 (1851-1855); 27 (1855-1862).

ALADRÉN, Gabriel. "Ascensão social e inserção econômica de ex-escravos: o caso do liberto Pedro Gonçalves (Rio Grande do Sul, século XIX)". Nuevo mundo mundos nuevos, [online], 2009.

AMARAL, Sharyse P. do. Escravidão, liberdade e resistência em Sergipe: Cotinguiba, 18601888. Tese (Doutorado em História), Universidade Federal da Bahia, Salvador, 2007.

AMSSBV, Livros e Batismos (LB) 13 (08/12/1876 a 20/03/1881).

APEJE, Hermeroteca, Folhinhas de Algibeira, 1852; 1853.

BARROS, Surya Aaronovich P. de. Universo letrado, educação e população negra na Parahyba do Norte (século XIX). Tese (Doutorado em Educação), Universidade de São Paulo, São Paulo, 2017.

CÂMARA, Bruno A. Dornelas. O "retalho" do comércio: a política partidária, a comunidade portuguesa e a nacionalização do comércio a retalho, Pernambuco, 1830-1870. Tese (Doutorado em História), Universidade Federal de Pernambuco, Recife, 2012.

CARVALHO, Marcus J. M de. Liberdade: rotinas e rupturas do escravismo. Recife (18221850). Recife: Editora da UFPE, 1998.

Os caminhos do rio: negros canoeiros no Recife na primeira metade do século XIX. Afro-Ásia, Salvador, n. 19/20, p. 75-93, 1997.

CHALHOUB, Sidney. Precariedade estrutural: o problema da liberdade no Brasil escravista (século XIX). História Social, Campinas, n. 19, p. 33-62, 2. sem. 2010.

COSTA, Valéria. Trajetórias negras: os libertos da Costa d'África no Recife, 1846-1890. Tese (Doutorado em História Social), Universidade Federal da Bahia, Salvador, 2013

Monica da Costa e Tereza de Jesus: africanas libertas, status e redes socias no Recife oitocentista. In: XAVIER, Giovana; FARIAS, Juliana B.; GOMES, Flávio. Mulheres negras no Brasil escravista e do pós-emancipação. São Paulo: Selo Negro, 2012, p. 98-111.

Revista da ABPN • v. 12, n. Ed. Especial - Caderno Temático: "Africanos,

escravizados, libertos biografias, imagens e experiências atlânticas” • agosto de 2020, p. 288-319 
Herdei e deixei de herança! Africanos e crioulos no Recife pós-abolição. Revista do Instituto Arqueológico, Histórico e Geográfico Pernambucano, Recife, n. 64, p. 165-193, 2011.

DIÁRIO DE PERNAMBUCO, "Página Avulsa", 13 jun. 1856 apud MELLO, J. A. G. de. Diário de Pernambuco: economia e sociedade no II Reinado. Recife: Editora Universitária UFPE, 1996.

FARIA, Sheila de M. Mulheres forras: riqueza e estigma social. Tempo, Rio de Janeiro, n. 9, p. 65-92, 2000.

. A colônia em movimento: fortuna e família no cotidiano colonial. Rio de Janeiro: Nova Fronteira, 1998.

FARIAS, Juliana B. et al. Cidades negras: africanos, crioulos e espaços urbanos no Brasil escravista do século XIX. São Paulo: Alameda, 2006.

FERNADES, Florestan. A integração do negro na sociedade de classes: o legado da "raça branca". 5. ed. São Paulo: Globo, 2008. v. 1.

FREIRE, Regina Célia Lima Xavier. A conquista da liberdade: libertos em Campinas na segunda metade do século XIX. Campinas: Centro de Memória; Editora da Unicamp, 1996.

FREYRE, Gilberto. Sobrados \& mocambos: decadência do patriarcado rural e desenvolvimento do urbano. 15. ed. rev. São Paulo: Global, 2004.

GOMES, Flávio; SOARES, C. E Líbano. Negras minas no Rio de Janeiro: gênero, nação e trabalho urbano no século XIX. In: SOARES, Mariza de Carvalho. (org). Rotas atlânticas da diáspora africana: da Baía do Benin ao Rio de Janeiro. Niterói: EdUFF, 2007, p. 191-224.

. História de quilombolas: mocambos e comunidades de senzalas no Rio de Janeiro, século XIX. Ed. rev. e ampl. São Paulo: Companhia das Letras, 2006.

GRAHAM, Maria. Diário de uma viagem ao Brasil. Belo Horizonte: Itatiaia; São Paulo: Edusp, 1990.

GUEDES, Roberto. Egressos do cativeiro: trabalho, família, aliança e mobilidade social (Porto Feliz, São Paulo, c.1798-c.1850). Rio de Janeiro: Mauad, 2008.

IAHGP, [Inventários] caixa 172, Joaquina da Conceição Araújo, 1867; caixa 179, [Testamento c/ inventário] João Joaquim José de Sant'Anna, 1862; caixa 214, Maria Antônia de Souza, 1872; José Francisco da Costa, 1873; caixa 229, Thereza de Jesus e Souza, 1873; caixa 269, Alexandre Rodrigues d'Almeida, 1880; caixa 328, Maria Thereza dos Passos, 1888; caixa 335, [Tesmanto c/ inventário] Domingos José Machado, 1890;

KOSTER, Viagens ao Nordeste do Brasil, 11. ed. 2 v. atual. Recife: Massangana, 2002.

LIMA, Ivana Stolze. Cores, marcas e falas: sentido da mestiçagem no Império do Brasil. Rio de Janeiro: Arquivo Nacional, 2003.

LARA, Silvia H. Escravidão, cidadania e história do trabalho no Brasil. Projeto História, São Paulo, 16, fev., 1998, p. 25-38.

Revista da ABPN • v. 12, n. Ed. Especial - Caderno Temático: "Africanos, escravizados, libertos biografias, imagens e experiências atlânticas” • agosto de 2020, 
LIMA FILHO, Trabalho e lei para os libertos na Ilha de Santa Catarina no século XIX: arranjos e contratos entre a autonomia e a domesticidade. Cadernos AEL, Campinas, v. 14, n. 26, p. 136-176, 2009.

MAC CORD, Marcelo. Artífices da cidadania: mutualismo, educação e trabalho no Recife oitocentista. São Paulo: Educampi, 2012.

MATTOSO, Kátia. Testamentos de escravos libertos na Bahia no século XIX: uma fonte para o estudo de mentalidades. Salvador: Centro de Estudos Baianos/UFB, 1979.

MORTARI, Claudia; DEBORTOLI, Gabrielli. Experiências em diáspora: africanas e africanos numa cidade portuária ao sul do Brasil (Desterro, 1810-1860). Revista Brasileira de Pesquisadores/as Negros/as (ABPN), [S.1.], v. 7, n. 17, p. 247-270, out. 2015. ISSN 21772770. Disponível em: https://bit.ly/3eu6S2O. Acesso em 13 de jun. 2020.

OLIVEIRA, Maria Inês C. de. Viver e morrer no meio dos seus: nações e comunidades africanas na Bahia do século XIX. Revista da USP, São Paulo, n. 28, p. 174-193, dez./fev. 1996.

O liberto, seu mundo e os outros. Salvador: Corrupio, 1988.

PATERSON, Orlando. Escravidão e morte social: um estudo comparativo. São Paulo: Edusp, 2008.

RECIFE (PE). MJPE, Registro de testamento [de] Antonio Domingos Ferreira e Catharina Maria da Conceição. Mapoteca 12, Gaveta G, Lv. 8 (14/11/1850 a 31/3/1853), fl. 102v-103v.

RECIFE (PE). MJPE, Registro de testamento [de] Gertrudes Joana Florinda. Mapoteca 13, gaveta F, Lv. 1875-1877, fls. 96v-97.

RECIFE (PE). MJPE, Registro de testamento [de] José Antônio Lopes. Mapoteca 12, gaveta G, Livro 8 (14/11/1850 a 31/03/1853), fl. 2v-4.

RECIFE (pe). MJPE, Registro de testamento [de] José Nicolao. Mapoteca 12, gaveta G, Lv. 8 (14/11/1850 a 31/01/1853), Registro de Testamento de José Nicolao, fl. 109v-112v.

RECIFE (PE). MJPE, Registro de testamento [de] Luduvina Maria da Conceição. Mapoteca 13, Gaveta F, Lv.1865-1866, fls. 17-18.

RECIFE (PE). MJPE, Registro de testamento [de] Margarida Maria da Conceição. Mapoteca 12, gav. G, Livro 8 (14/11/1850 a 31/03/1853), fl. 88v-90.

REIS, João José. Ganhadores: a greve negra de 1857 na Bahia. São Paulo: Companhia das Letras, 2019.

. Domingos Sodré, um sacerdote africano: escravidão, liberdade e candomblé na Bahia do século XIX. São Paulo: Companhia das Letras, 2008.

. Rebelião escrava no Brasil: a história do levante dos malês em 1835. Ed. rev. e ampl. São Paulo: Companhia das Letras, 2003.

De olho no canto, trabalho de rua na Bahia na véspera da Abolição. Afro-Ásia, Salvador, n. 24, p. 199-242, 2000.

Revista da ABPN • v. 12, n. Ed. Especial - Caderno Temático: "Africanos, escravizados, libertos biografias, imagens e experiências atlânticas” • agosto de 2020, 
RUSSEUL-WOOD, A. J. R. Escravos e libertos no Brasil colonial. Rio de Janeiro: Civilização Brasileira, 2005.

SCHANTZ, Ana Paula Dornelles. Libertos no Rio Grande de São Pedro: Porto Alegre e Viamão no final do século XVIII e início do XIX. Dissertação (Mestrado em História), Universidade Federal da Bahia, Salvador, 2009.

SILVA, Eduardo. Dom Obá II d'África, o príncipe do povo: vida, tempo e pensamento de um homem livre de cor. São Paulo: Companhia da Letras, 1997.

SILVA, Maciel H. C. da. Nem mãe preta, nem negra fulô: histórias de trabalhadoras domésticas em Recife e Salvador (1870-1910). São Paulo: Paço Editorial, 2016.

SOARES, Carlos E. L. Zungú: rumor de muitas vozes. Rio de Janeiro: Arquivo Público do Estado do Rio de Janeiro, 1988.

SOUZA, Robério S. Tudo pelo trablaho livre! trabalhadores e conflitos o pós-abolição (Bahia, 1892-1909). Salvador: Edufba;São Paulo: Fapesp, 2011.

THORNTON, John. A África e os africanos na formação do mundo atlântico, 1400-1800. Rio de Janeiro: Elsevier, 2004.

WISSENBACH, Maria Cristina Cortez. Sonhos africanos, vivências ladinas: escravos e forros em São Paulo (1840-1880). São Paulo: Hucitec, 1998.

Recebido 03/07/2020

Aprovado em 22/07/2020

Revista da ABPN • v. 12, n. Ed. Especial - Caderno Temático: "Africanos,

escravizados, libertos biografias, imagens e experiências atlânticas” • agosto de 2020, 